\title{
Sympatric plant speciation in islands?
}

\section{Arising from: V. Savolainen et al. Nature 441, 210-213 (2006)}

Comparative studies of populations, particularly with the help of molecular markers, are necessary to understand the mechanisms of speciation in isolated oceanic archipelagos. Savolainen et al. ${ }^{1}$ present comparative data on two endemic species of the palm genus Howea in Lord Howe Island, from which they infer that speciation was sympatric - that is, divergence had occurred in the absence of geographic isolation. However, the landscape of oceanic islands changes dramatically over time, with many disappearing under the sea after 6 million years or more, and Lord Howe Island is in a very late stage of its ontogeny. An alternative explanation, therefore, is that these two species did not evolve in situ but instead that they arose allopatrically after becoming geographically isolated at a time when the island was much larger and more diverse ecologically.

Aside from well-known mechanisms of chromosomal polyploidy, examples of homoploid sympatric speciation in plants are rare. Savo-lainen et al. ${ }^{1}$ present interesting comparative morphological, geographical, ecological and molecular (AFLP, or amplified DNAfragment length polymorphism) data regarding relationships between the two species of Howea palms endemic to Lord Howe Island. Considering that the distributions of the two taxa now overlap, the authors regard this as a good example of sympatric plant speciation. The difficulty with this interpretation is that it does not take into account island ontogeny and its possible impact on the two species. Sympat- ric speciation in islands, therefore, may still not have been convincingly demonstrated.

Lord Howe Island has a geomorphology that suggests strong erosion and surface loss, which correlates with its advanced age of 6.4-6.9 Myr. Dating from molecular sequences reveal the genus Howea to have diverged from progenitors 4.5-5.5 Myr ago, which is compatible with the island's age. By the same methods, the two species are judged to be $0.5-1.9 \mathrm{Myr}$ old, at which time the island would still have been much larger than today. Loss of terrestrial area is more rapid during the later stages of island ontogeny, when the sea covers the last parts of the land.

Many other examples exist of sympatric and closely related plant species in oceanic islands. Such a pattern is evident among six species of Robinsonia (Asteraceae) from Masatierra Island in the Juan Fernandez archipelago in Chile $^{2}$. My colleagues and I have estimated that this island, which is about $4 \mathrm{Myr} \mathrm{old}^{3}$, has lost up to $95 \%$ of its original surface area ${ }^{4}$. The pattern we now see can best be interpreted as refugial, with these species being packed together (sympatrically) in the remaining small surface area. The original mode of speciation would have been ecogeographical (allopatric).

An alternative hypothesis for the origin of the two endemic species of Howea on Lord Howe Island, therefore, is by allopatric speciation in different ecological (perhaps calcarenite) zones, when the island was much younger and much larger. The low degree of AFLP divergence between the two species of
Howea does notnecessarily argue for sympatric speciation. Island congeners typically show very little genetic divergence in DNA sequences and isozymes ${ }^{5}$. An absence of broad surveys prohibits generalizations at this point, but the limited AFLP data available indicate that verylittle divergence may have occurred between closely related species in islands that have speciated allopatrically ${ }^{6}$.

Before jumping to conclusions about sympatric speciation in oceanic islands, we need to exercise caution and factor in our best estimate of island geomorphic and habitat change, which together have had a major impact on genetic and species diversity?.

TodF. Stuessy

Department of Systematic and Evolutionary Botany, University of Vienna, 1030 Vienna,

Austria

e-mait: tod.stuessy@univie.ac.at

1. Savolainen, V.etal. Nature 441, 210-213(2006)

2. Sanders, R. W, Stuessy, T. F, Marticorena, C.\& Silva, Q M. Opera Bot. 92, 195-215 (1987).

3 Stuessy, T.F. Foland, K A., Sutter, L. F, Sanders, R. W. \& Silva, O.M.Sdence 225,49-51(1984)

4. Stuessy, T.F. Crawford D. L, Marticorena, C.\& Rodriguez, R. in Evolution and Spedation of island Plants (eds Stuessy, T. F. \& Ono, M.) 121-138 (Cambridge Univ. Press 1998)

5. Crawford, D.J.\& Stuessy, T. F. in Evolution and Diversification of Land Plants (eds Wwatsuki, K \& Raven P. H.) 249-267 (Springer Tolyo, 1997).

6. Parsons, Y. M.\& Shaw, K L.Mol. Ecal. 10, 1765-1772 (2001).

7. Stuessy, T.F. Greimler, L \& Dimb\&ck T. Bial. Skrift. 55, 89-10i (2005).

doi: $10.1038 /$ nature 05216

\section{EVOLUTIONARYBIOLOGY}

\section{Savolainen et al. reply}

\author{
Replying to: T. F. Stuessy Nature 443, doi10.1039/nature05216 (2006)
}

Stuessy ${ }^{1}$ questions our conclusions of sympatric speciation in a case study of palms on Lord Howe Island ${ }^{2}$ and proposes an alternative hypothesis, whereby the two Howea species evolved allopatrically when the island was larger and less eroded. Stuessy also argues that low genetic divergence does not necessarily indicate speciation in sympatry ${ }^{1}$. We agree that it is important not to jump to conclusions, but we have good estimates of the size and geological history of Lord Howe Island at the time of the speciation event ${ }^{3,4}$, and both are fully compatible with sympatric speciation. Stuessy also misinterprets the results from our
AFLP (amplified DNA-fragment length polymorphism) genome scan: we did not assert that low AFLP divergence per se is evidence for sympatric speciation, but rather that the distribution of these genetic divergence values across the genome is strongly supportive of speciation with gene flow involving disruptive or divergent selection ${ }^{2}$.

Evidence from bathymetry around the island indicates that its past extent has not exceeded $30 \mathrm{~km}$ long by $23 \mathrm{~km}$ wide ${ }^{3}$; today the island is roughly $12 \mathrm{~km}$ long and, on average, $1.5 \mathrm{~km}$ wide. The original height of the island is estimated to be $1,000 \mathrm{~m}$, comparable with $875 \mathrm{~m}$ for Mount Gower today ${ }^{3}$. The presence of an evenly distributed, wave-cut platform surrounding Lord Howe Island indicates that erosion has been mainly coastal and equal from all sides. Consequently, Quaternary calcarenite deposits, which created divergent ecological selection pressures conducive to Howea species divergence ${ }^{2}$, have formed evenly around the island ${ }^{4}$; these are so closely intercalated with volcanic rocks that allopatric speciation due to ecogeographic isolation, as Stuessy proposes ${ }^{1}$, is unrealistic.

The geomorphological history of Lord Howe Island must also be seen in the light of the breeding system of Howea. Even at its greatest extent, the island would have been small compared with the gene dispersal capacity of these woody, wind-pollinated outcrossers. Indeed, our analysis of molecular variance revealed extremely homogeneous population structure in both palms, which is compatible 